\title{
PERBEDAAN UKURAN KANUL SUCTION TERHADAP PERUBAHAN KADAR SATURASI OKSIGEN DI RUANG ICU RSUD DR. MOEWARDI TAHUN 2015
}

\author{
Yunita Kusuma Wardhani ${ }^{1}$ \\ ${ }^{1}$ Kementerian Kesehatan Politeknik Kesehatan Surakarta Jurusan Keperawatan \\ Diterima : 18 Mei 2018, Disetujui : 2 Juni 2018
}

\begin{abstract}
Abstrak
Background: Patients treated at the ICU room one of them have an exhalation problem. Most of them needed a helping breath like a mechanical ventilator. Patients who needed a mechanical ventilator have a poor cough, so these sekret will be plaquein the lung cavity. A step to reduce plaque thefore doing a suction care. There are many action can be noticed to doing a suction care is by choosing canule measure. This research works through to a distingushment of canule measure for change to titrate saturasi oxygen on rigged patient mechanical ventilator at spatial ICU RSUD Dr. Moewardi. Method: The type of this research is quasi experimental with pre is and post's test test control design's group. The Result: This observational result there is canule measure difference for change to titrate saturasi oxygen on rigged patient mechanical ventilator at ICU RSUD Dr. Moewardi Surakarta. kanul's measure 12F have greater influence appealed by kanul's measure $10 F$ which is as big as 0.001, meanwhile canule measure $10 F$ has changing as big as 0.029. Conclusion: The difference canule measure suction having for change to titrate saturasi oxygen.
\end{abstract}

Keywords: Canule 10F, Canule 12F, Saturasi's Rate Oxygen, Ventilators Rigged Patient Mechanical.

PENDAHULUAN

Intensive Care Unit (ICU) merupakan ruang rawat rumah sakit dengan staf dan perlengkapan khusus ditujukan untuk mengelola pasien dengan penyakit, trauma atau komplikasi yang mengancam jiwa. Peralatan standar di Intensive Care Unit (ICU) meliputi Endotracheal Tube (ETT) untuk membantu usaha bernafas melalui ventilasi mekanik. Salah satu indikasi klinik pemasangan alat endotracheal tube ataupun pemasangan alat ventilator mekanik adalah gagal nafas (Musliha, 2010). Gagal napas merupakan kegagalan sistem respirasi dalam pertukaran gas $\mathrm{O} 2$ dan $\mathrm{CO} 2$ serta masih menjadi masalah dalam penatalaksanaan medis.
Secara praktis, gagal napas didefinisikan sebagai $\mathrm{PaO} 2<60 \mathrm{mmHg}$ atau $\mathrm{PaCO} 2>50 \mathrm{mmHg}$. Salah satu kondisi yang dapat menyebabkan gagal nafas adalah obstruksi jalan nafas, termasuk obstruksi pada endotrakeal tube pada pasien yang terpasang alat ventilator mekanik.

Penanganan untuk obstruksi jalan napas akibat akumulasi sekresi pada ventilator mekanik adalah dengan melakukan tindakan penghisapan lendir (suction) dengan memasukkan selang kanul suction melalui hidung/ mulut/ endotracheal tube yang bertujuan untuk membebaskan jalan nafas, mengurangi retensi sputum dan mencegah infeksi paru. 
(Nurachmah\& Sudarsono, 2000 dalam Kitong, 2014).

Tindakan suction endotracheal tube pada pasien terpasang ventilator mekanik merupakan intervensi yang sering dilakukan oleh perawat untuk pasien kritis. Hasil study pendahuluan di ruang ICU RSUD Moewardi Surakarta, fenomena yang ditemui di ruang intensif diantaranya pasien dengan permasalahan pada gangguan pernafasan yang memerlukan tindakan suction.

Berdasarkan hasil wawancara dengan perawat di ruang ICU, menyatakan bahwa ukuran kanul suction yang sering digunakan yaitu menggunakan ukuran $10 \mathrm{~F}$ dan $12 \mathrm{~F}$. peneliti tertarik untuk meneliti pengaruh perbedaan ukuran selang suction terhadap perubahan kadar saturasi oksigen pada pasien yang terpasang ventilator mekanik di RSUD Moewardi.

\section{METODE PENELITIAN}

Jenis rancangan penelitian ini menggunakan quasi experimental dengan pre test and post test control group design. Semua responden diukur saturasi oksigennya menggunakan pulse oxymeter sebelum dan setelah tindakan suction. Dalam penelitian ini menggunakan uji $t$ test dan t-independent test. Penelitian telah dilakukan pada tanggal 29 Maret-15 Mei 2015 dilakukan di ICU RSUD Dr. Moewardi. Populasi dalam penelitian ini adalah semua pasien yang dirawat di ruang intensif yang terpasang ventilator mekanik Rumah Sakit Dr. Moewardi, sedangkan sampel penelitian pasien yang terpasang ventilator mekanik yang dilakukan suction.

Kriteria inklusi penelitian ini pasien yang dirawat diruang ICU RS Dr. Moewardi yang mengalami gagal nafas, pasien menggunakan alat bantu nafas ventilator mekanik, pasien terdapat berlendir/sekret dan akan dilakukan tindakan suction, pasien dewasa dengan usia 20-59 tahun sedangkan kriteria ekslusi penelitian ini pasien yang sedang dilakukan tindakan Resusitasi Jantung Paru (RJP), pasien yang menggunakan alat bantu nafas ventilator mekanik dengan mode CPAP, pasien dengan kadar saturasi kurang dari $85 \%$.

Instrumen dalam penelitian ini menggunakan kanul suction ukuran 10F dan $12 \mathrm{~F}$ untuk tindakan kepada pasien yang terpasang ventilator mekanik. Untuk instrumen observasi menggunakan lembar Standar Operasional Prosedure (SOP).

Prosedur penelitian ini responden diberi perlakuan tindakan suction menggunakan ukuran kanul 10F dan 12F. Sebelum dilakukan tindakan suction semua responden diukur saturasi oksigen dan setelahnya juga diukur saturasi oksigen. Setelah mendapat persetujuan langkah selanjutnnya fokus pada etika penelitian. Pengolahan data dilakukan setelah kegiatan mengumpulkan data, selanjutnya dilakukan langkah-langkah sebagai berikut editing, coding, tabulating. Teknik analisa data meliputi uji univariat dan uji bivariat.

\section{HASIL PENELITIAN}

Dalam penelitian ini diuraikan tentang hasil penelitian untuk perbedaan ukuran kanul suction dalam melakukan tindakan suction di Ruang Intensif Care Unit (ICU) RSUD Dr Moewardi di Surakarta tahun 2015 antara lain karakteristik responden, uji bivariat yaitu uji pairet-test dan independent sample test. 
Tabel 1. Distribusi frekuensi jenis kelamin responden menggunakan ukuran kanul 10F

\begin{tabular}{cccc}
\hline No & Jenis kelamin & $\mathrm{n}$ & $\%$ \\
\hline 1 & Perempuan & 8 & 47.1 \\
2 & Laki - laki & 9 & 52.9 \\
\hline Total & 17 & 100 &
\end{tabular}

Tabel 1 menunjukkan bahwa jumlah reponden yang laki-laki dan perempuan hampir sama yaitu responden jenis kelamin laki-laki sebanyak 9 responden atau sebesar 52,9\%, sedangkan untuk jenis kelamin perempuan sebanyak 8 responden atau sebesar 47,1. Dapat disimpulkan bahwa distribusi frekuensi jenis kelamin responden menggunakan ukuran kanul $10 \mathrm{~F}$ lebih banyak terjadi pada responden dengan jenis kelamin laki-laki.

Tabel 2. Distribusi frekuensi jenis kelamin responden menggunakan ukuran kanul 12F

\begin{tabular}{cccc}
\hline No & Jenis kelamin & $\mathrm{n}$ & $\%$ \\
\hline 1 & Perempuan & 9 & 52.9 \\
2 & Laki - laki & 8 & 47.1 \\
\hline Total & 17 & 100 &
\end{tabular}

Tabel 2 menunjukkan bahwa jumlah jenis kelamin reponden yang menggunakan ukuran kanul ukuran $12 \mathrm{~F}$ hampir sama yaitu pada responden jenis kelamin perempuan sebanyak 9 responden atau sebesar $52,9 \%$, sedangkan untuk jenis kelamin laki-laki sebanyak 8 responden atau sebesar $47,1 \%$. Dapat disimpulkan bahwa distribusi frekuensi jenis kelamin responden yang menggunakan ukuran kanul 12F lebih banyak terjadi pada responden dengan jenis kelamin perempuan.
Tabel 3. Distribusi frekuensi berdasarkan umur responden menggunakan kanul ukuran $10 \mathrm{~F}$

\begin{tabular}{cccc}
\hline No & Umur & $\mathrm{n}$ & $\%$ \\
\hline 1 & Dewasa awal (20-30 tahun) & 5 & 29.4 \\
2 & Dewasa akhir (31-59 tahun) & 12 & 70.6 \\
\cline { 1 - 3 } Total & 17 & 100 & \\
\cline { 1 - 3 } & &
\end{tabular}

Tabel 3 dapat disimpulkan bahwa distribusi frekuensi berdasarkan umur responden yang menggunakan ukuran kanul $10 \mathrm{~F}$ banyak terjadi pada dewasa akhir antara usia 31-59 tahun yaitu sebanyak 12 responden atau sebesar $70.6 \%$.

Tabel 4. Distribusi frekuensi berdasarkan umur responden menggunakan kanul ukuran $12 \mathrm{~F}$

\begin{tabular}{cccc}
\hline No & Umur & $\mathrm{N}$ & $\%$ \\
\hline 1 & Dewasa awal (20-30 tahun) & 4 & 23.5 \\
2 & Dewasa akhir (31-59 tahun) & 13 & 76.5 \\
\hline \multicolumn{2}{c}{ Total } & 17 & 100 \\
\hline
\end{tabular}

Tabel 4 dapat disimpulkan bahwa distribusi frekuensi berdasarkan umur responden dengan menggunakan ukuran kanul $12 \mathrm{~F}$ paling banyak pada dewasa akhir antara usia 31-59 tahun yaitu sebanyak 13 responden atau sebesar $76.5 \%$.

Tabel 5. Distribusi saturasi oksigen responden sebelum dan sesudah dilakukan tindakan suction menggunakan ukuran kanul 10F

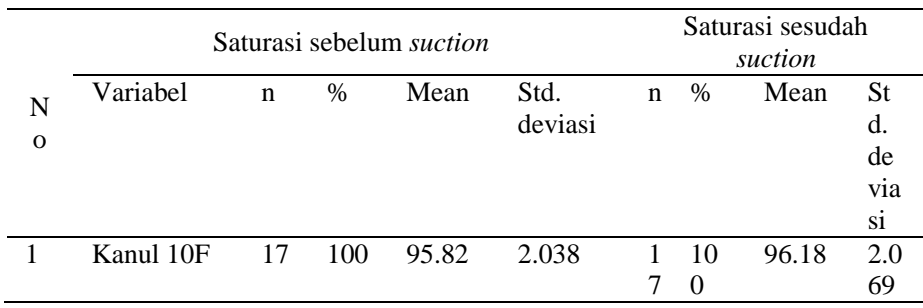

Tabel 5 menunjukkan bahwa sebelum dilakukan tindakan suction menggunakan ukuran kanul $10 \mathrm{~F}$ didapatkan nilai mean sebesar 95.82, setelah dilakukan tindakan suction 
mengalami peningkatan nilai mean yang didapatkan sebesar 96.18, maka dapat disimpulkan peningkatan yang terjadi sebesar 0.36.

Tabel 6. Distribusi saturasi oksigen responden sebelum dan sesudah dilakukan tindakan suction menggunakan ukuran kanul $12 \mathrm{~F}$

\begin{tabular}{llllllllll}
\hline & \multicolumn{4}{c}{ Saturasi sebelum suction } & \multicolumn{4}{c}{ Saturasi sesudah suction } \\
\cline { 2 - 9 } & Variabel & $\mathrm{n}$ & $\%$ & Mean & $\begin{array}{l}\text { Std. } \\
\text { deviasi }\end{array}$ & $\mathrm{n}$ & $\%$ & Mean & $\begin{array}{l}\text { Std. } \\
\text { deviasi }\end{array}$ \\
\hline 1 & $\begin{array}{l}\text { Kanul } \\
12 \mathrm{~F}\end{array}$ & 17 & 100 & 94.35 & 2.548 & 17 & 100 & 96.41 & 2.808 \\
\hline
\end{tabular}

Tabel 6 menunjukkan bahwa hasil mean sebelum dilakukan tindakan suction menggunakan ukuran kanul $12 \mathrm{~F}$ sebesar 94.35, dan sesudah dilakukan tindakan suction nilai mean yang didapatkan nilai mean sebesar 96.41, maka dapat disimpulkan peningkatan yang terjadi sebesar 2.06.

Kedua persyaratan untuk Uji paired sample $t$ - test telah terpenuhi, yaitu yang pertama bahwa sebaran data berdistribusi normal. Persyaratan kedua, yakni dengan uji homogenitas varian membuktikan bahwa data homogen. Pada penelitian ini didapatkan data berdistribusi tidak homogen. Menurut sopiyudin (2011), syarat untuk uji paired t-test dan $t$ -independent sample test yang pertama data berdistribusi normal dan yang kedua variansi data bisa homogen atau heterogen. Setelah persyaratan terpenuhi maka dilakukan Uji paired sample $t$-test dan uji $t$-independent sample test. Untuk membuktikan hipotesis yang telah ditetapkan.
Tabel 7. Analisis uji paired sample test menggunakan kanul ukuran $10 \mathrm{~F}$

\begin{tabular}{ccccccc}
\hline \multirow{2}{N}{$\begin{array}{c}\mathrm{N} \\
\mathrm{o}\end{array}$} & Variabel & $\mathrm{n}$ & $\%$ & Mean & $\begin{array}{c}\text { Std. } \\
\text { Deviation }\end{array}$ & -value \\
\hline 1 & $\mathrm{SpO}_{2}$ sebelum & 1 & 1 & & & \\
& suction & 7 & 0 & 95.82 & 2.038. & \\
& & 0 & & & \\
\cline { 1 - 5 } 2 & $\mathrm{SpO}_{2}$ sesudah & 1 & 1 & & & \\
& suction & 7 & 0 & 96.12 & 2.069 & \\
& & & 0 & & & \\
\hline
\end{tabular}

Dari tabel 7 menunjukkan bahwa perubahan kadar saturasi oksigen menggunakan kanul ukuran $10 \mathrm{~F}$ mempunyai nilai $p$ value sebesar 0.029 , nilai mean sebelum dilakukan tindakn suction sebesar 95.82 dan sesudah dilakukan tindakan suction sebesar 96.18. dapat disimpulkan bahwa terjadi peningkatan kadar saturasi oksigen.

Tabel 8. Analisis uji paired sample test menggunakan kanul ukuran $12 \mathrm{~F}$

\begin{tabular}{ccccccc}
\hline & \multicolumn{5}{c}{ Sebelum-sesudah $\mathrm{SpO}_{2}$ menggunakan kanul 12F } \\
\cline { 2 - 5 } No & Variabel & $\mathrm{n}$ & $\%$ & Mean & $\begin{array}{c}\text { Std. } \\
\text { Deviati } \\
\text { on }\end{array}$ & p-value \\
\hline 1 & $\begin{array}{c}\mathrm{SpO}_{2} \text { sebelum } \\
\text { suction }\end{array}$ & 17 & 100 & 94.35 & 2.548 & 0,002 \\
\cline { 1 - 5 } & $\begin{array}{c}\mathrm{SpO}_{2} \text { sesudah } \\
\text { suction }\end{array}$ & 17 & 100 & 96.41 & 2.808 & \\
\hline
\end{tabular}

Dari tabel 8 menunjukkan bahwa perubahan kadar saturasi oksigen menggunakan kanul ukuran $12 \mathrm{~F}$ mempunyai nilai $p$ value sebesar 0.002 , nilai mean sebelum dilakukan tindakn suction sebesar 94.35 dan sesudah dilakukan tindakan suction sebesar 96.41. dapat disimpulkan bahwa terjadi peningkatan kadar saturasi oksigen.

Tabel 9. Hasil Analisis Uji Independent Sample Test Sebelum Dilakukan Tindakan Suction

\begin{tabular}{ccccccc}
\hline & \multicolumn{5}{c}{ Saturasi sebelum dilakukan suction } \\
\cline { 2 - 7 } No & Variabel & $\mathrm{n}$ & $\%$ & Mean & $\begin{array}{c}\text { Std. } \\
\text { Deviati } \\
\text { on }\end{array}$ & p-value \\
\hline 1 & Kanul 10F & 17 & 100 & 95.82 & 2.038 & 0,025 \\
2 & Kanul 12F & 17 & 100 & 94.52 & 2.322 & \\
\hline
\end{tabular}


Tabel 9 menunjukkan bahwa ada perbedaan sebelum dilakukan tindakan suction menggunakan ukuran kanul $10 \mathrm{~F}$ dan $12 \mathrm{~F}$ memiliki $p$ value sebesar 0.025 , sehingga dapat disimpulkan bahwa sebelum melakukan tindakan suction mempunyai $p$-value sebesar 0.025 .

Tabel 10. Hasil analisis uji independent sample test sesudah dilakukan tindakan suction

\begin{tabular}{ccccccc}
\hline \multirow{5}{*}{ No } & \multicolumn{6}{c}{ Saturasi sesudah dilakukan suction } \\
\cline { 2 - 7 } & Variabel & $\mathrm{n}$ & $\%$ & Mean & $\begin{array}{c}\text { Std. } \\
\text { Deviation }\end{array}$ & p-value \\
\hline 1 & Kanul 10F & 17 & 100 & 95.08 & 2.058 & 0,002 \\
2 & Kanul 12F & 17 & 100 & 98.41 & 1.228 & \\
\hline
\end{tabular}

Tabel 10 menunjukkan bahwa

Perbedaan menggunakan ukuran kanul $10 \mathrm{~F}$ dan $12 \mathrm{~F}$ mempunyai nilai $p$ value sebesar 0.002. Sedangkan dilihat dari nilai mean yang menggunakan ukuran $12 \mathrm{~F}$ mengalami peningkatan lebih besar dibanding menggunakan ukuran kanul 10F, yaitu sebesar 98.41. Maka dapat disimpulkan ada perbedaan kadar saturasi oksigen sesudah dilakukan tindakan suction menggunakan kanul ukuran $10 \mathrm{~F}$ dan $12 \mathrm{~F}$.

\section{PEMBAHASAN}

Pembahasan dalam penelitian ini menjelaskan tentang hasil penelitian diatas serta membandingkan dengan teori yang ada. Hasil penelitian tersebut sesuaikah dengan teori yang ada atau tidak. Sesuai dengan hasil penelitian yang akan dibahas dalam pembahasan ini adalah analisis univariat meliputi umur responden, dan uji bivariat meliputi kadar saturasi oksigen sebelum dan sesudah dilakukan tindakan suction dengan ukuran kanul yang berbeda.

Menurut Santrock, J.W (2008), usia dewasa dibagi menjadi dua yaitu dewasa awal usia antara 20-30 tahun dan dewasa akhir antara usia 31-59 tahun.
Berdasarkan hasil data penelitian diatas, diketahui bahwa tindakan suction dengan menggunakan kanul ukuran $10 \mathrm{~F}$ maupun 12F banyak terjadi pada usia dewasa akhir yaitu pada usia antara 31-59 tahun.

Dari data yang telah didapatkan berdasarkan uji berpasangan (paired $t$ test) antara sebelum dan sesudah dilakukan tindakan suction mengalami perubahan, baik menggunakan ukuran kanul 10Fr maupun ukuran kanul 12Fr, adanya perubahan kadar saturasi oksigen. Hal ini sesuai dengan teori yang dijelaskan oleh Setianto (2007) evaluasi dari hasil yang diharapkan setelah melakukan tindakan penghisapan sekret endotrakeal adalah meningkatnya suara napas, menurunnya Peak Inspiratory Pressure, menurunnya ketegangan saluran pernapasan, meningkatnya dinamik campliance paru, meningkatnya tidal volume, adanya peningkatan dari nilai arterial blood gas, atau saturasi oksigen yang bisa dipantau dengan pulse oxymeter, hilangnya sekresi pulmonal. Adapun tujuan setelah dilakukan tindakan suction seperti yang dijelaskan Lynn (2011) antara lain mempertahankan patensi jalan nafas, mengurangi kerja pernafasan dengan mengeluarkan secret, merangsang reflek batuk, mencegah infeksi.

Penelitian yang dilakukan oleh Kitong (2014) dengan judul "Pengaruh Penghisapan Lendir Endotracheal Tube (ETT) Terhadap Pengaruh Kadar Saturasi Oksigen Pada Pasien Yang Dirawat di Ruang ICU RSUP Pro. Dr. R. D. Kandau Manado" menunjukkan hasil bahwa adanya perbedaan kadar saturasi oksigen sebelum dan sesudah diberikan tindakan penghisapan lender dimana terdapat selisih nilai kadar saturasi oksigen sebesar 
$5,174 \%$ dan nilai $p$-value $=0,000 \quad(\alpha<$ $0.05)$.

Untuk mengetahui perbedaan antara kanul $10 \mathrm{~F}$ dan $12 \mathrm{~F}$ menggunakan uji t-independent sample test. Hasil yang didapatkan yaitu sebesar $0.002 \%$, atau nilai $\mathrm{p}<0.05$ yang artinya ada perbedaan perubahan saturasi oksigen setelah dilakukan tindakan suction menggunakan ukuran kanul yang berbeda. Peningkatan saturasi oksigen menggunakan kanul ukuran $12 \mathrm{~F}$ lebih besar dibanding dengan ukuran kanul $10 \mathrm{~F}$, peningkatan kadar saturasi oksigen menggunakan ukuran kanul 10F sebesar 95.88, sedangkan untuk ukuran kanul 12F yaitu sebesar 98.41.

Menurut Kozier (2009), ukuran kanul suction steril untuk dewasa adalah 10 - 16 Fr. Pada pasien yang terpasang ET pengukuran menggunakan rule of thumb untuk selang suction yaitu menggadakan ukuran millimeter jalan napas buatan. Misal diameter ET $6 \mathrm{~mm} \mathrm{x}$ $2=12$. Ukuran selang suction yang aman 12 Fr (French Units). Hal tersebut sejalan dengan yang diungkapkan oleh Umar (2004), diameter kateter suction bagian luar tidak boleh melebihi setengah dari diameter bagian dalam lumen tube/jalan nafas buatan. Diameter kateter yang lebih besar akan menimbulkan atelektasis sedangkan kateter yang terlalu kecil kurang efektif untuk menghisap sekret yang kental. Penelitin yang berlawanan dengan penelitian ini yaitu Nofiyanto, $M$. (2013) membahas tentang perbedaan nilai saturasi oksigen $\left(\mathrm{SpO}_{2}\right)$ berdasarkan ukuran kateter suction pada tindakan open suction di ruang general intensive care unit RSUP Dr. Hasan Sadikin Bandung, membedakan ukuran kanul $12 \mathrm{~F}$ dan $14 \mathrm{~F}$ hasil yang didapatkan terjadi penurunan saturasi oksigen pada kedua kelompok, ukuran 14 Fr menurunkan saturasi oksigen lebih banyak $(2,18 \%)$ daripada $12 \mathrm{Fr}$ $(1,18 \%)$ dengan nomor ETT responden 7 $\mathrm{mm}$. Terdapat perbedaan rerata selisih saturasi oksigen yang bermakna antara kelompok 12 Fr dan 14 Fr $(p=0.001), \alpha=$ 0,025 . Hal ini karena semakin besar ukuran kateter suction akan semakin mempersempit lumen ETT untuk masuknya udara atmosfir dan memperbesar oksigen paru yang terhisap. Yang perlu diingat adalah setiap melakukan tindakan suction, bukan hanya sekretnya yang dihisap akan tetapi oksigen di paru juga dihisap dan alveoli bisa kollaps. Kanul suction yang baik adalah efektif menghisap sekret dan resiko trauma jaringan yang minimal. Teori yang dijelaskan oleh Kozier (2009), teknik untuk meminimalkan atau menurunkan komplikasi meliputi lakukan pengisapan hanya bila diperlukan, penggunaan teknik steril, hiperinflasi. Hiperoksigenasi, ukuran kateter yang aman dan memasukkan salin.

Penelitian ini membahas mengenai perubahan kadar saturasi oksigen dengan ukuran kanul yang berbeda, prinsipnya sebelum dilakukan tindakan suction diukur kadar saturasi oksigen, setelahnya diukur kadar saturasi oksigen. Hasil dari penelitian ini terjadi peningkatan yang berbeda dengan menggunakan kanul ukuran $10 \mathrm{~F}$ dan $12 \mathrm{~F}$ yaitu $p$ value sebesar $0.002(p<0.05)$.Dengan demikian dapat disimpulkan penelitian mengenai perbedaan ukuran kanul suction pengaruhnya terhadap perubahan saturasi oksigen mempunyai perbedaan, khususnya ada peningkatan setelahnya dilakukan tindakan suction.

\section{KESIMPULAN DAN SARAN}

Berdasarkan hasil penelitian yang telah dilakukan tentang perbedaan ukuran 
kanul suction dengan perubahan kadar saturasi oksigen pada pasien yang terpasang ventilator mekanik di ruang ICU RSUD Dr. Moewardi tahun 2015 sebagai berikut dapat ditarik kesimpulan bahwa :

1. Ada perubahan kadar saturasi oksigen sebelum dan sesudah dilakukan tindakan suction menggunakan kanul ukuran 10F.

2. Saturasi oksigen mengalami perubahan setelah dilakukan tindakan suction menggunakan kanul ukuran $12 \mathrm{~F}$.

3. Terdapat perbedaan yang signifikan setelah dilakukan tindakan suction menggunakan kanul ukuran 10F dibanding kanul ukuran 12F

Berdasarkan hasil penelitian ini, ukuran kanul suction yang diteliti mempunyai pengaruh yang signifikan terhadap perubahan kadar saturasi oksigen, untuk itu peneliti menyarakan bagi perawat di ruang ICU supaya dalam melakukan tindakan suction diharapkan memilih ukuran kanul yang tepat disesuaikan dengan ukuran ETT yang digunakan.

Untuk penelitian lebih lanjut terhadap perubahan kadar saturasi oksigen peneliti menyarankan hendaknya lebih fleksibel waktunya dan menggunakan sampel di beberapa ICU rumah sakit serta dilakukan dengan tim sehingga responden bisa terpantau dan bisa lebih tergeneralisasi. Sebaiknya juga tentang faktor-faktor yang tidak dapat terkontrol, besar kemungkinan variabel yang tidak terkontrol bisa berpengaruh juga terhadap perubahan kadar saturasi oksigen pada pasien yang menggunakan alat bantu nafas ventilator mekanik di ICU.

\section{DAFTAR RUJUKAN}

Asmadi. (2008). Teknik Prosedural Keperawatan Konsep dan Aplikasi Kebutuhan Dasar Lien. Salemba Medika: Jakarta

Corwin, J. E,. (2001). Buku Suku Patafisiologi (hands book of pathophysiologi). Jakarta: EGC.

Fox, N. (2002). Pulse Oxymetry. Nursing Times. 98, 65-67.

Giuliano, K. K. (2006). Knowledge of Pulse Oximetry Among Critical Care Nurses. Dimentsions of Critical Care Nursing. 25, 44-49.

Gwinnutt, C. (2006). Clinical Anaesthesia 2nd edn. Oxford: Blackwell Publishing.

Hidayat, A. (2005). Pengantar Ilmu Keperawatan Anak. Edisi 1. Jakarta: Salemba.

Higgins, D. (2005). Pulse Oxymetry. Nursing Times.

Ignatavicius. (1999). Medical Surging Nursing: A Nursing Process Approach (ed. 2). Philadeplhia: W. B . Saunders Company.

Istiqomah. (2009). Infeksi Nosokomialpneumonia. (online). http://materibidan.blogspot.com/20 09/10/infeksi-nosokomialpneumonia.html. diakses pada tanggal 19 Januari 2015

Jevon, P., \& Ewens, B. (2009). Pemantauan Pasien Kritis seri ketrampilan klinis esensial untuk perawat edisi kedua. Jakarta: Erlangga.

Kementrian Kesehatan Republik Indonesia, Profil Kesehatan Indonesia. (2010). Kementrian Kesehatan Republik Indonesia 2012: Jakarta (online), (http://www.depkes.go.id/downloa ds/PROFIL_DATA_KESEHATA 
N_INDONESIA.pdf, diakses tanggal 17 Januari 2015 )

Kitong, B. I. (2014). Pengaruh Tindakan Penghisapan Lendir Endotracheal Tube Terhadap Kadar Saturasi Oksigen Pada Pasien Yang Di Rawat Di Ruang ICU RSUP Prof. Dr. R.D Kandou Manado (online) (ejournal.unsrat.ac.id/indek.php/jk p/article/view/5275). diakses tanggal 11 Desember 2014)

Kozier, B., \& Erb, G. (2002). Kozier and Erb's Techniques in Clinnical Nursing 5th Edition. New Jersey: Pearson Education.

Leach, R. (2004). Critical Caremedicine At A Glance. Oxford: Blackwell Publishing.

Lemeshow S, et al. (1993). Adequacy of Sample Sizein Health Studies. Chichester: John Wiley \& Sons.

Lynn, D. (2011). AACN procedure manual for critical care 6th edition. St Louis Missouri: Elsevier saunders.

Morton. (2011) dan Praticia, G. (2011). Keperawatan Kritis: Pendekatan Asuhan Holistic; Alih Bahasa, Nike Budhi Subekti...[et al]; editor edisi bahasa indonesia, Fruriolina Ariani, Alfrina Hanny, Esty Wahyuningsih.-Ed.8.Jakarta: EGC

Mathews, P. J. (2005). The Lastest In Respiratory Care. Nursing Management Supplemenet : Critical Care Choices.

Murti, B. (2013). Desain dan ukuran Sampel untuk Penelitian Kuantitatif dan Kualitatif di Bidang Kesehatan. Yogyakarta : Gadjah Mada University Press.
Musliha. (2010). Keperawatan Gawat Darurat. Yogyakarta : Nuha Medika.

Nofiyanto, M. (2013). Perbedaan Nilai Saturasi Oksigen (Spo2) Berdasarkan Ukuran Kateter Suction Pada Tindakan Open Suction Di Ruang General Intensive Care Unit RSUP Dr. Hasan Sadikin Bandung (online) http://pustaka.unpad.ac.id/archives /128770/\# diakses pada tanggal 2 Februari 2015

Notoatmodjo, S. (2010). Metodologi Penelitian Kesehatan, (Eds.Revisi). Bandung: Rineka Cipta.

Nurachmah, E., S,. (2000). Buku Saku Keperawatan Medikal Bedah. Jakarta:EGC.

Nursalam. (2003). Konsep dan penerapan metodologi penelitian ilmu keperawatan. Jakarta : Salemba Medika

Pontoppidan H, Geffin B, Lowenstein E. Acute respiratory failure in the adult.N English J Med. 1972 Oct 19;287(16):799-806 (online) http://www.ncbi.nlm.nih.gov/pubm $\underline{\text { ed/4560519 diakses pada tanggal }}$ 20 Januari 2015

RSDM. (2014). Standar Operasional Prosedure (SPO) Menghisap Lendir (Suction). RSUD Dr. Moewardi. Surakarta

RSUP Dr. Kariadi. (2004). Protap Suction Endotracheal. (online). http://digilib.unimus.ac.id/files/dis k1/112/jtptunimus-gdlwiyotog2a2-5560-3-bab2.pdf. Diakses pada tanggal 15 Januari 2015 
Santjaka, A. (2009). Bio statistik. Purwokerto : Global Internusa.

Santrock, J.W. (2008). Psikologi Perkembangan. Jakarta : Prenada Media Group

Saryono. (2011). Metodelogi Penelitian Kesehatan. Jogjakarta : Mitra.

Setiadi. (2007). Konsep dan Penulisan Riset Keperawatan. Yogyakarta : Graha. Ilmu.

Setiyohadi, B. (2007). Buku Ajar Ilmu Penyakit Dalam Jilid II Edisi IV. Jakarta: Pusat Penerbitan Departemen Ilmu Penyakit Dalam Fakultas Kedokteran Universitas Indonesia.

Smeltzer, S.C dan Bare, B.G. (2001). Buku Ajar Keperawatan Medikal Bedah. (Edisi 8). Jakarta : EGC.

Sugiyono. (2007). Metode Penelitian Kuantitatif Kualitatif dan $R \& D$. Bandung: Alfabeta.

Sujatmi, S. (2010). Efektifitas Lama Waktu Suction 10 dan 15 Detik Terhadap Kadar Saturasi Oksigen (O2) Perifer pada Pasien Stroke di $R$. ICU RSUD Kebumen (online) (http://digilib.stikesmuhgombong.a c.id/gdl.php?mod=browse\&op=rea d\&id=jtstikesmuhgo-gdl$\underline{\text { srisujatmi-289 diakses tanggal } 3}$ Januari 2015)

Sundana, K. (2008). Ventilator : pendekatan praktis di unit keprawatan kritis: Bandung. CICU Bandung

Syafni, S.R. (2012). Efektifitas Penggunaan Close Suction System dalam Mencegah Infeksi Nosokomial Ventilator Assosiated Pneumonia (VAP) pada Pasien Dengan Ventilator Mekanik. (online). (http://repository.unri.ac.id/bitstrea $\underline{\mathrm{m} / 123456789 / 1916 / 1 / \mathrm{JURNAL} . p d}$ f. Diakses pada tanggal 5 Januari 2015)

Timby, B.(2009). Fundamental Nursing Skills and Concepts. Philadelphia: Lippincot William \& Wilkins.

Wahyono. (2007). Pelaksanaan Prosedur Suction. (online). https://ojantikareborn.wordpress.co $\underline{\mathrm{m} / 2011 / 04 / \text { diakses pada tanggal }}$ 19 Januari 2015.

Welch, J. (2005). Pulse Oximeters. Biomedical Instrumentation and Technology, 125-130.

Wiyoto. (2010). Hubungan Tingkat Pengetahuan Perawat Tentang Prosedur Suction Dengan Perilaku Perawat Dalam Melakukan Tindakan Suction di ICU Rumah Sakit dr. Kariadi Semarang (Online),

(http://digilib.unimus.ac.id/gdl.php ?mod=browse \&op=read=jtptunim us-gdl-wiyotog2a2-5560, diakses tanggal 11 November 2014)

Zifrianita. (2012). Pengaruh Tindakan Suction dengan Hiperoksigenisasi Terhadap Saturasi Oksigen di Ruang HCU RSUP Fatmawati Tahun 2012 (online). http://psikumj.ac.id/library/index.php?p=sho $\underline{\text { w_detail\&id=1268, diakses pada }}$ tanggal 15 Desember 2015. 